\title{
THE URBAN PROFILES OF PEACE TOURISM IN ARAB CITIES: OPPORTUNITIES FOR CHANGE TOWARDS SUSTAINABILITY. CASE STUDY: AS-SALT (JORDAN) AND CONSTANTINE (ALGERIA) CITIES
}

\author{
Foued BENGHADBANE ${ }^{*}$ \\ University of Oum El Bouaghi, Institute of Management of the Urban Techniques, Laboratory for the evaluation \\ of the quality of use in architecture and the environment (LEQUAE), Algeria, e-mail: fouad.benghadbane@gmail.com \\ Sawsan KHREIS \\ Yarmouk University, Faculty of Tourism and Hotel Management, Irbid, Jordan, e-mail: sawsankhries@ yahoo.com
}

\begin{abstract}
Citation: Benghadbane, F., \& Khreis, S. (2021). THE URBAN PROFILES OF PEACE TOURISM IN ARAB CITIES: OPPORTUNITIES FOR CHANGE TOWARDS SUSTAINABILITY. CASE STUDY: AS-SALT (JORDAN) AND CONSTANTINE (ALGERIA) CITIES. GeoJournal of Tourism and Geosites, 38(4), 1175-1188. https://doi.org/10.30892/gtg.38424-758
\end{abstract}

\begin{abstract}
Tourism is not only considered as a stimulator for the social and economic development for countries, but also it contributes in spreading peace and enhancing negotiation, comprehension, and exchanging cultures among people in the light of the increased tourist demand. Arab countries confronted fluctuation and instability in the number of tourist arrivals due to security disturbances, conflicts and the vanishing of peace opportunities. In this regard, this research reveals the urban features for some Arab countries in achieving peace tourism because it is considered as touristic destinations that enhance heritage tourism due to the existence of the whole touristic features. The study sheds the lights on both As-Salt (Jordan) and Constantine (Algeria) cities. For the purpose of highlighting the opportunities of peace tourism by its urban features for changing towards sustainability by adopting that combine tourism development, peace building, and heritage conservation in both Arab cities. The researchers also required the development of certain tactical techniques to attain clear results in the research, the study relied on qualitative research in reviewing many documents and research related to both tourism and peace. In addition, field investigations contributed to providing data and information during the period from (2015-2018), like that the observation and interviews conducted with the local community in both cities. Results of the research, represented mainly in the presence of opportunities for peace tourism, which are reinforced by the specificity of the urban characteristics of the two cities, and its clear role in establishing a culture of peace, understanding, dialogue and exchange of cultures, which requires defining a model for the relationship between the development of tourism, peace and heritage in the cities of Salt and Constantine and which is based on tourism planning with the effective participation of different stakeholders.
\end{abstract}

Key words: peace tourism, urban features, opportunities, sustainability, heritage tourism, As-Salt and Constantine cities

$* * * * * *$

\section{INTRODUCTION}

Tourism is considered a cornerstone for the economies of various countries due to its rapid growth and vital role in increasing the national income. Therefore, it receives a great deal of attention, particularly in countries that lack economic resources with a high unemployment rate. The world has become unequal in terms of peace and security, which are the most important tourist requirements due to changes in tourist behaviors. On the one hand, here are some countries that enjoy the sovereignty of security, stability, and peace. On the other hand, there are some countries in which violence and chaos spread lead to high economical costs that accounted for 13.7 trillion dollars in 2012 and 14.3 trillion dollars in 2014 or 13.4\% from the global gross domestic product (Institute for Economics and Peace, 2015). Meanwhile, the contribution in tourism in the gross domestic product has globally increased and accounted for $2.3 \%$ since 2005 . As such, the foreign expenditure on the tourism has increased with the growth of visitors' exports by $3.4 \%$. Generally speaking, the average number of international tourists has increased all over the world than global average that accounted for 828 million in 2005 to 1.184 billion in 2015. All of which enabled the tourism to become as a primary source for income and job opportunities for various countries that receive tourists (World Travel \& Tourism Council, 2016).

In this respect, the tourism constitutes a motivation for achieving peace and security according to a causal mechanism that works on both individual and international levels for achieving the flow in tourism liquidity among countries and even inside one country since the money and cultures are exchanged among societies. Also, peace tourism facilitates diplomatic and commercial relations among countries in a political touristic environment (Herath, 2010).

Peace means, in the domain of tourism; providing appropriate conditions aiming at eliminating violence, and therefore conditions can be improved or avoided through the role of tourism encouraging travel and displacement to improve international understanding, where tourism can assume the role of diplomacy that emerges in interactions and formal relations between governments, as tourism offers opportunities for tourists to interact with host communities to learn more about their personalities, beliefs, aspirations, culture, political tendencies and perception towards life. Peace

\footnotetext{
* Corresponding author
} 
revolves around equity, social justice, harmony, and cooperation between individuals of different cultural models and the absence of cultural violence and structural (Jimenez and Kloeze, 2014).

The peace tourism constitutes a type of tourism that plays a role in creating urban sustainability because it is considered as a well-established phenomenon in social structures, networks, and behavioral aspects by improving relations, human awareness, and fostering understanding between members of society. Tourism gains increasingly the strength for peace by improving various perceptions and situations in the current diverse society that is surrounded by multiple political events, the phenomenon of terrorism, and political instability in various parts of the world. The supported discourse for the role of tourism is considered as a peace maker by assuming that the communication resulting from travel might positively impact on the international politics and enhances global peace by reducing cultural and Psychological gaps among individuals (Farmaki, 2017). In order to achieve "peace tourism", many international agreements were concluded by the international bodies that control and regulate the tourism industry and policy makers, which are led by the United Nations World Tourism Organization (UNWTO), the United Nations agency specialized in dealing with tourism and presenting its strongest advocates, as well as other bodies related to tourism and politics aimed at peace. The first declaration of peace and tourism was in 1948 i.e. after the Second World War issued by the United Nations for human rights. After that the International Bureau of Social Tourism was established in 1963, followed by the Helsinki Agreement in 1975, and then the declaration of world tourism in 1980 in Manila (Philippines) as "Tourism is a vital force for peace and international understanding" (Wohlmuther and Wintersteiner, 2014,18; Salazar, 2006, 324). In 1985, the "Tourism Rights Law and Tourism Law" was announced in Sofia (Bulgaria) due to the role of tourism in improving mutual understanding and bringing people together for enhancing international cooperation. The United Nations has declared that tourism has paved the way to peace and this was confirmed at the AUN Conference of Environment and Development on June 14, 1992. The Global Code of Ethics for Tourism In Santiago (Chile) was established in 1999 through direct and unstructured spontaneous contacts that arise between men and women in different cultures and lifestyles, since tourism represents a vital force of peace and a factor for friendship and understanding between people all over the world (Salazar, 2006), and in Amman (Jordan) a declaration was made about "peace through tourism" which was adopted at the World Summit "Peace through Tourism" on November 11, 2000 (Kunwar, 2006).

In addition, the peace tourism aims at restoring social balance, encouraging conflict resolution, and eliminating prejudice and poverty through cultural exchange and assimilation between society and tourists. This helps in promoting peace, and its tourism activities help in achieving peace in the minds of tourists by promoting cultural exchange and assimilation between society and tourists to form a harmonious society that is economically strong and free from conflict and injustice, which promotes harmony within a balanced and healthy environment (Mohanty et al., 2019).

In fact, the issue of the relationship between tourism and peace is extremely important for researchers in the tourism sector. Some of them believe that tourism can be an important element in promoting peace opportunities in different geographical environments by the communication resulting from travel among individuals and tourists that reduces cultural as well as psychological gaps and barriers. Also, the communication and continuity between them after the return of tourists to their countries (Causevic and Lynch, 2011), particularly after the widespread use of social media, which increased the role of tourism as a factor for change, and there are those who indicate that tourism benefits from peace and is not a reason to replace it (Moufakkir and Kelly, 2010). Regardless this difference between influence and impact, there are some researchers who have worked on separating this difference and emphasized that tourism necessarily leads to the existence and spread of peace, as tourism cannot develop in a field that is dominated by conflicts and disputes because tourists do not travel to these destinations. Consequently, the gaps between different societies will not disappear (Rowen, 2014).

Therefore, it is necessary to promote tourism and peace together by taking advantage of various international experiences aimed at the welfare of tourists and the promotion of the tourist destination, as well as promoting a culture of peace among the host communities and incoming tourists (Moufakkir and Kelly, 2010), and encourage communication between them so as to understand the various relationships and within the local governance of tourism. Under the prevailing atmosphere of peace, tourism works to promote more peaceful, and sincere relations among individuals with multiple dimensions linked to the existence of justice, respect for human rights, the welfare of the public interest, the protection of global security and the maintenance of a culture of peace (D'Amore, 1988).

In this context, this study will shed the lights on both As-Salt (Jordan) and Constantine (Algeria) cities in order to clarify the role of urban features in achieving tourism for peace, which was a primary driver for improving many tourist destinations, such as heritage, environment, and business, etc. for elevating them towards Sustainability, particularly AsSalt city, which is considered as the museum city, in which the practice of heritage tourism prevails due to its multiplicity of heritage sites that was obvious in completing many urban projects there (Trillo et al., 2020). All of which, played a role in the arrival of tourists, especially as it is a Jordanian city in a country that is characterized by peace and surrounded by areas of tension and conflict. Jordan was able to maintain its stability and security of His Majesty King Abdullah II who played a role in laying down four important reform programs, represented in "Jordan First" in 2002, then the "National Agenda" in 2005, "We are all Jordan" In 2006, and the "National Dialogue Committee" in 2011 (Ababsa, 2011), which made him eligible to receive the Catholic "Misbah Al-Salam/ The lamp of peace" award in the Monastery of St. Francis of Assisi in Italy, on March 29, 2019 (https://ofm.org/blog/king-abdullah-ii-of-jordan-receives-the-lamp-of-peace-award-in-assisi/).

On the other hand, Constantine city has witnessed a noticeable change in its urban features after the completion of many urban projects that supported its tourism activity by increasing the number of tourists coming there, the expansion and the diversification of tourism services, such as hotels, entertainment areas, and infrastructure coinciding with the rule of peace provided The Civil Harmony Law and the Charter for Peace and Reconciliation endorsed by President "Abdelaziz 
Bouteflika", where a general and comprehensive referendum was held on September 29, 2005, during which the Charter accounted for 97\% approval, and implemented as a law on February 28, 2006 (http: / /lipietz.net) for ending all the conflicts and disputes that broke out in the beginning of the nineties (the black decade), and the high percentage (97\%) reflects the desire of the whole Algerian community for peace. Hence, an increase in the number of local and foreign tourists' arrivals as one of the most important destinations tourism in which local community improves tourism services and ensures the well-being of tourists in light of the new orientation of the state to develop the tourism sector.

The researchers choose the cities of Salt (Jordan) and Constantine (Algeria) for many reasons:

First of all both of them are Arab cities sharing many geographical features, knowing that the first one is located in the Arab Mashrek (Asia) and the second one is situated in the Maghreb (Africa). Secondly, the local community of these cities lives in peace leading to the creation of the appropriate environment for peace tourism. Therefore, this research focuses on the importance of urban features in establishing peace tourism in As-Salt (Jordan) and Constantine (Algeria) cities.

\section{Objectives of the Study}

The study aims at:

- Clarifying the urban features of As-Salt and Constantine cities, which reflect the possibility of achieving their peace tourism.

-Highlighting the various types of the practiced tourism in both As-Salt and Constantine cities the light of the multiplicity of tourism features.

-The method of constituting urban features that are attributed by understanding, dialogue and cultural exchange between societies.

-Clarifying the mechanism of employing peace tourism in promoting change towards sustainable tourism with the participation of the local community in both As-Salt and Constantine cities.

\section{Significance of the Study}

The significance of the study stems from:

-The importance of the subject "Peace Tourism" within a strong correlation between influence and impact.

-The topic of peace tourism is a recent trend in Arab cities in the sustainable tourism industry, particularly when it deals with the cities of As-Salt (Jordan) and Constantine (Algeria) that are considered the first studies that tackle this type of tourism at the level of Arab cities.

- Peace environment existing in both As-Salt and Constantine cities since their inception and development over time through the urban landmarks constructed on them, which represent at the same time the features of sustainable tourism development within a rational local tourism management.

\section{LITERATURE REVIEW}

Peace represents a key indicator in choosing tourism destinations for travel, recreation, leisure and exchanging cultures within the intended destination communities as well as the contribution of the local community is considered as an ambassador of peace in preserving and enhancing the welfare of individuals in society and the natural environment, and due to this growing importance, many researchers have worked to clarify the nature of the relationship that links tourism and peace between influence and vulnerability through many academic scientific research. Northern Ireland's experience in resuming peace tourism is considered one of the first international experiences (Boyd, 2000), after suffering from terrorism that has lasted 30 years, and for this we have to take advantage of the achieved peace to revive its economy, and the heritage landmarks spread among it were one of the most important attractions, which requires marketing as opportunities that must be exploited to promote heritage tourism from the perspective of sustainability. In addition, business tourism is concentrated in the capital "Belfast". Consequently, Northern Ireland constitutes a destination of peace tourism that is rich in its natural and human heritage as indicated by Boyd in 2000 that the development of heritage and cultural tourism in Northern Ireland depends on its achieved peace.

It is Followed by "Shin" in 2005 who clarifies the importance of peace and tourism in light of the growing demand of global tourism, while many tourist destinations suffer from instability, which requires a study looking at the coexistence between tourism and peace and its implications with the focus on the existing relationship between peace and tourism in Korean Demilitarized Zone DMZ, where political issues play an important role in this region, and establishing political stability is essential for the development in South and North Korea within the framework of tourism cooperation between them, which will have a positive impact in the presence of a peace and security environment that was supported and confirmed by the attitudes and positive perceptions of international and local tourists towards peace and cooperation in this region (DMZ) as a tourist destination and a place of peace between the two Koreas (Shin, 2000).

It is worth mentioning that the development of the concept of peace through tourism dates back to "Salazar" as one of the academic experts in tourism. In his research published in 2006 the method of building a culture of peace through tourism (Salazar, 2006). After that, interest in peace tourism continued in many previous studies that focused on different aspects with the aim of establishing them according to different cases of tourist destinations in the world. Southerners who visited North Korea's Kumgang mountain resort, which these tourists viewed as a site of peace tourism could combine "the policy of rapprochement between the rising sun" and "the mutual strategy between inter-Korean". The project of this resort combines cultural, contradictory, and idealized spaces at the same time. Therefore, the future of tourism in the resort opens several directions for research at the local level upon restarting it for exploring the perceived value resulting from the new political environment of tourists (Lee et al., 2012). 
Besides, Nepal provides a model for more destinations of peace tourism, which Upadhayaya explained it, in 2016, in his study on Nepal that requires the presence of tourist security, as it combines manifestations of violence and natural hazards in a region that highlights the highest mountain peaks in the world, where it is considered a destination for adventure, recreation, and ecotourism tourism. However, it is fraught with some both security factors and internal obstacles between management and employment in corporate tourism institutions, such as major hotels, casino, and airline companies, which lead to some kind of violence. Also, some sudden natural accidents, such as earthquakes, avalanches, landslides, floods, and severe snow, which requires promote coping strategies to prevent, mitigate, and manage the tourism crisis that arise in different types of security incidents (Upadhayaya, 2016). In Indonesia, peace tourism has received great attention, as evidenced by "the vision of the management of the tourist destination" in "Kuta Bali" on the island of Bali, which seeks to cultivate a culture of peace among the tourists' arrivals and raise their number by presenting a statue of a "miniature" monument to "Ground Zero". "As a peace memorial, and the history book of the memorial as a souvenir for tourists, packaging symbolic products to realize the values of peace, providing a special place for tourists to pray, and ensuring a tour of the region to attract the interest of tourists by providing interpreters to explain the memorial, to re-explore and mobilize the potential of peace as a new tourism product in "Kuta Bali" that allows a new experience based on peace tourism products to be introduced as reached by Ariana and his colleagues in their study which was carried out in 2016 (Ariana et al., 2016).

In 2017, "Does" and "Kawano" discussed peace tourism in a participatory approach to the world heritage site of "Hiroshima" and 'Miyajima"' island to be a kiss for peace tourism, which was strengthened after the visit of the US President in 2016 and selected for the Nobel Peace Prize in 2017 as a major tourist destination in Japan, it can provide a culture of peace for the local community as well as for incoming tourists who know their numbers increase, as well as the possibility of transferring "the participatory heritage of the atomic bomb experience through "peace tourism"' (Does and Kawano, 2017). On the other hand, "Mishra" and "Verma" tackled the great role that tourism in India plays as an engine for sustainable economic development directed peace, where it was concluded that tourism is gaining a significant capacity due to its positive impact on the sustainable development of India, which requires the development of plans and appropriate policies to promote tourism as a means of achieving sustainable development and peace (Mishra and Verma, 2017).

Also, "Zulafqar" in 2018 dealt with the analysis of the impact of peace on tourism in Jammu and Kashmir that are regarded as the most attractive tourist destination because they contain many tourism features, such as fertile green valley, favorable climate, snow-capped mountains, springs, and temples, particularly in Gulmarg, Phalgam, Dal Lake, Wular Lake which deserve seeing their tourist attractions. Jammu and Kashmir region have received national and international attention due to the increased number of tourists' arrivals that has not known been stabled due to the turmoil, particularly in the last thirty years as a result of the armed struggle and the accompanying destruction of public buildings, heritage monuments, bridges, hospitals, the private institutions, and commercial shops with the beginning of peace in the region since 2007, the tourism sector recovered and many investment projects were found related to the development of fine handcrafted products and the creation of adventure places such as trekking and skiing had a great impact on increasing the number of international tourists due to the peace process, which requires achieving sustainable tourism as a first step in this region that has rich and multiple tourism resources (Zulafqar, 2018).

In 2019, "Mohanty" and his colleagues clarified the role of tourism in promoting peace through the development of sustainable community-based tourism by linking the environment and the local community with tourists and other important aspects taking Odisha city in India as a spatial area for this study, which follows the policy of decentralization in tourism planning with active participation of all members of society in all its groups, trying to achieve creativity for local peace in the city of "Odisha" to provide the tourist with satisfaction as well as leading the welfare of the host population, especially as it has multiple and diverse tourism resources such as beaches, palms, forests, biodiversity, mountains and temples (Mohanty et al., 2019). In 2020, Seyfi and his colleagues studied the issues of tourism, peace, and sustainability in destinations subject to economic sanctions such as Iran that seem as a tool for fostering peace instead of armed intervention. Thus, it is primordial to promote sanctions and tourism as well as a force for peace and reconciliation process relying on international relations, political science and decision-makers in the tourism and hospitality industry (Seyfi et al., 2020).

Pedersen (2020) confirms that tourism reinforces the existence of peace. Moreover, it is considered as a "vital force for the peace and international relations that are reinforced through global tourism originations aiming at enhancing peaceful relations through national and cultural borders (Pedersen, 2020). With the growing importance of peace tourism, IGI Global published in 2021 a collective book, under the direction of Louis D'Amore, entitled "Role and impact of tourism in peace building and conflict transformation", offering an approach to peace through tourism, an analysis of the dynamics of tourism in international relations and a presentation of some studies focusing on peace building, cultural interactions and international relations (Da Silva et al., 2021). Accordingly, peace tourism combines two basic concepts: "tourism" and "peace" in a relationship of influence and vulnerability where natural and human hazards are absent and tourism security is resolved. It depends on the active participation of local communities in creating the appropriate atmosphere for exchanging cultures and establishing principles of tolerance and harmony in a voluntary framework of the state within its desired development policies that aimed at achieving sustainable ecotourism, enhancing heritage and cultural tourism, and stimulating medical tourism and business tourism.

\section{Methods and Procedures}

The study relied on exploring urban features in both As-Salt and Constantine cities to promote peace tourism based on qualitative research in reviewing many documents and research related to both tourism and peace as well as trying to mix the two concepts to clarify the nature of the potential relationship between tourism and peace as an affect and effect (Pratt 
and Liu, 2016). In addition, field investigations that contributed in providing data and information during the period from 2015-2018 in which both cities visited to coexist with their urban components to realize their role in achieving peace tourism that was based on observation without forgetting in-depth interviews conducted with the local community in both cities and the tourists arrivals there in order to understand the extent of the awareness gained in dialogue and exchange of cultures (Farmaki, 2017). The research also developed certain tactical techniques to reach clear results (Figure 1).
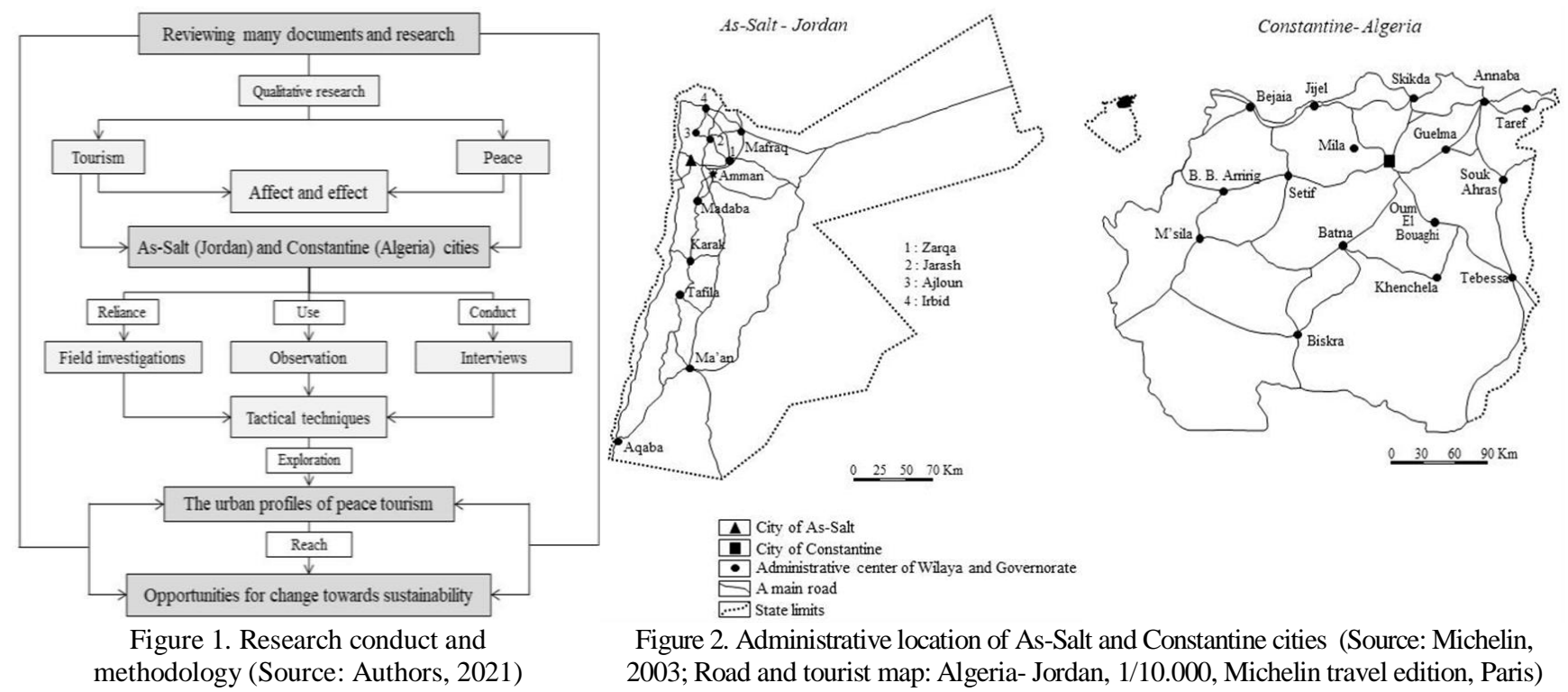

The geographical situation for the corridor of peace in both As-Salt and Constantine cities:

As-Salt is located northwest of the Hashemite Kingdom of Jordan at latitude $32,02^{\circ} \mathrm{N}$ and longitude $35,44{ }^{\circ} \mathrm{E}$, within the $\mathrm{Al}$ Balqa mountains at an altitude of 880 meters above the surface level, and 28 kilometers northwest of the capital Amman (Greater As-Salt Municipality, 2016). On the road leading to Jerusalem passing through Wadi Shuaib, and far some kilometers to the south from the road leading to Nablus as well as from the road that is connecting As-Salt to Jerash and Ajloun. Also, its location constitutes a ground break point between the Jordanian Badia and the internal plateaus in the east, the Jordan Valley, and the Palestinian highlands in the west.

This site enabled it to become as a land transportation link that connects these regions to each other with a network of major roads (Qtiashat et al., 2018). Therefore, As-Salt city is characterized by the privacy of its location on the road to peace because it is regarded as the Christian pilgrim crossing to Jerusalem and Bethlehem (west), and the Islamic pilgrimage towards Mecca and Medina (to the south), and a transit center for trade caravans from the ports of the Arabian Peninsula to the Levant and from there to Europe and North Africa. The city of As-Salt represents the administrative center of Al Balqa Governorate, and its population amounted for 72,576 people in 2004 which represents $21.3 \%$ of the total population of Al Balqa Governorate estimated by the same year to 344,985 (Hyasat and Alnahleh, 2014). In respect of Constantine city, it is located in the east of Algeria within $431 \mathrm{~km}$ from Algiers, in the high plateau region at a latitude of $36.23^{\circ}$ north and longitude $7.35^{\circ}$ east and at an altitude of 640 meters (Larouk, 1984).

It constitutes a point that links between the northern hill region and the southern desert region as well as the crossroads of the main national roads in the east of Algeria that flow and distribute traffic and flows with neighboring cities, such as Annaba, Skikda, Jijel, Guelma, Oum El Bouaghi, Batna and Setif, and Constantine is the third largest Algerian city (418,672 population in 2008) (ONS, 2011) after Algiers and Oran (Figure 2). It is worth mentioning that Constantine, through its long history over 2,500 years played an important role as a crossroads in all successive civilizations, such as (Numidia, Roman, Arab Islamic, Turkish and French), which reflects the importance of security and stability prevailing throughout the history (Benghadbane, 2020).

\section{Site specificity suitable for peaceful coexistence:}

As-Salt and Constantine cities attributed by their mountainous sites which had a great impact on the nature of their interrupted urban fabric between its morphological units. As-Salt city is located on three main mountains, namely: Jabal Al-Qalaa, Jabal Al-Jada'a and Jabal Al-Salalam, that surround the central square "Al- Ain" of the city, which reach the Valley of the Kurds and Wadi Al-Salt that has a great impact in dividing the city of As-Salt into distant neighborhoods, located on the peaks, slopes, and feet of the mountains, which make them different in their height and in the proportion of slope, as it effectively affected the construction of roads, their extension, and direction (Almatarneh, 2013). It took paths in line with the valleys and the nature of the prevailing land slope in them, which led to the allocation of these roads for vehicles and for men and that have many stairs due to the slope, the floor areas allocated for construction are very small, which made the various uses of the land in the city overlap among them, as the buildings differ in their height in terms of the number of floors and their spatial distribution, and the morphology of the city appears in three coexisting forms between them. These are the combined shape, the striped shape, and the scattered shape (Qtiashat et al., 2018). 
The city of Constantine is created on a defensive position on the mountain "Le Rocher", surrounded by a valley "Rhumel" on almost all sides, which crosses deep gorges. Also, when it was created, it was "Fort" on "Le Rocher" rock and then developed along it outside the rock on the mountains and surrounding hills, such as (Mount "Sidi M'Cid", the "beautiful scenery" hill, "Mansoura" Plateau ...) (Benghadbane, 2020). All of which affected the road network plan that was distinguished with its steep slopes and parallel with elevation lines as well as the spread of suspension bridges to connect the various neighborhoods whose construction style and height have been linked to the topographical features of the city. However, the city has gradually become a center for exchanges, trade, economic, and social attraction. After that it has become a city of radiation for science and culture for all parts of the region, which enabled it to become the "Arab Culture Capital of 2015" (Boukerzaza, 2015). As a result of the great role of peace prevailing in both cities that ensure their survival despite the disappearance of the defense factor, since the battle of dignity in 1968, the city of As-Salt witnessed stability and security and continued its urban growth outside three mountains. Similarly, Constantine city, since the French occupation in 1830 achieved that. Thus, the city continued to grow and expand outside the rock (Le Rocher) to extend over the hills and mountains around it, in order to ensure its urban, social connectivity, and cohesion. These topographic units were connected to a number of bridges (Benghadbane and Khreis, 2019).

\section{A multi-clan social structure in harmony and solidarity:}

In fact, the location of the two cities helped in diversifying their social structure. As-Salt city arose in the form of human agglomerations, i.e. neighborhoods that include a group of lanes separated between them by main streets, from which stairs and corridors are branched. These agglomerations have developed and spread in the foothills of the mountains to meet with each other at the feet of these mountains in the place of "Al Ain" Square, which has become as a commercial center of the city (Zalloum and Tarrad, 2020). "Al-Awamleh" and "the Kurds" agglomerations were among the first to settle in the foothills of the Citadel during the 16th century. At the beginning of the 19th century, the Qatishat agglomeration was formed in a central area between the "Al-Awamleh" and the "Kurds", followed by "Al-Jada" and the "Al-Ghorabae" at the beginning of the twentieth century, as the "Al-Ghorabae" agglomeration is inhabited by immigrant merchants who came to the city for work, trade, most of them are from Palestinian cities (Jerusalem, Nazareth and Hebron, particularly from Nablus city is often called the "Nablusiya"' agglomeration and Damascus, Lebanon, Turkey.

In fact, immigrants continued to arrive to As-Salt especially after 1967, and they organized their place of residence in the form of lanes, as each neighborhood became known as the geographical area, such as the "Al-Sawarfa" neighborhood relative to the village of "Surif", and the neighborhood Al-Yatawi is a relative of the village of Yatta in Palestine (Fakhoury and Haddad, 2014).

It is worth mentioning that the social structure of the population of As-Salt city despite its multiple geographical origins was affected by a tribal system, kinship, and lineage, which has increased the strength of its social association that is based on solidarity and cooperation in facing various problems, and this has led to the creation of a relatively homogeneous society without the existence of economic and social differences between the population (Khirfan, 2013), with the absence of class among the neighborhoods of the city without forgetting the role of mosques and the multiple churches scattered within the city that work to spread awareness of social connectedness (Alzoabi, 2004).

Constantine has witnessed peace and security since Ottoman protection (1500 AD), which attracted the inhabitants of the neighboring countryside to settle there. In addition, providing housing and work as a result of commercial and economic vitality that extended its influence until Tunisia and Libya under the rule of Saleh Bey who made it as the capital of the Eastern Province and increased the social link between Algerian families and Ottoman families with kinship, lineage, and formed a societal product known as "Karagleh" (Larouk, 1984). Also, several mosques were established in the city the most famous one is "Sidi Kettani" mosque that activated the cultural and educational life in the city. The city's population after the French occupation (in 1866 AD) reached 37,026 people, divided into three social groups (Muslims, Jews and Christians) (Pagand, 1994), in a way appropriate to the divisions that the colonizer made by dividing some of the main ways of the city on the rock to turn it into 03 major neighborhoods, such as the European neighborhood, the Islamic city, and the Jewish quarter. Despite the variation in religions and the high population density, the city remained stable and secure, for each category of its services and facilities despite the presence of the occupation, and Muslims have endeavored to preserve the bonds of good relations between them and the Jews in social and economic relations. Regardless the prolonged disdain of the Jews, the Jews have gone a long way in insulting the Algerian Muslims until the events of August 3-11, 1934, (Attal, 1996), without forgetting the events that occurred during the National Liberation Revolution (1954-1962). This is normal in a city under foreign occupation, until the independence of Algeria on July 5, 1962, in order to give the room for peace and security in Constantine city until the present time.

\section{Various Cultures Based on Education}

Cultural values are necessary for the emergence of the two cities. As-Salt study included the first secondary school (Salt Secondary School in 1923 AD) in Tel Al-Djadour, within the framework of the reform movement, which was concerned with education and coincident with the activity of the missions coming from Europe that contributed in the establishment of many sectarian schools for the education of Muslims and Christians (Alzoabi, 2004), such as AlSayfiya School, the English School, the Greek Orthodox School and the Monastery of the Latin School. It should be noted that As- Salt Secondary School has graduated seven presidents from the governments, more than 70 ministers, and a large number of senior civil and military officials. As a matter of fact, cultural and educational activities of both religions have increased upon the establishment of Al-Balqa Applied University in Al-Mansheya area in 1997, followed 
by the establishment of the King Abdullah II School of Excellence in 2004 for the preparatory and secondary stage in As-Salt which is regarded as the first of its kind in all parts of the Kingdom.

As for the city of Constantine, the cultural life was revitalized by its embrace of the headquarters of the Association of Muslim Scholars led by Sheikh "Abdel Hamid ben Badis", and the headquarters of party "The Star of North Africa". It also published several newspapers in the Arabic language, such as "Al-Manbar" and "Al-Ummah" newspapers, the newspaper of the nation and the trade unions, and the "Chehab" magazine, which were all expressing the social and economic life of the city's residents with the aim of resurrecting peace in the North Africa region (Larouk, 1984), as cultural life developed after Independence in 1962with the presence of the French Cultural Center, the Cultural Center "Abdel Hamid ben Badis", "Mohamed El-Aid Al Khalifa" (Figure 3) and "Malek Haddad" (Figure 4) in the city center of Constantine. In fact, the cultural exchange between different people increased through the presence of the "Prince Abdel Qader" University for Islamic Sciences in the "beautiful scenery" hill, which receives students of various nationalities for learning that also includes a mosque for the establishment of prayer, and has taken in its design the Andalusian oriental style and its elegant decoration of Islamic architecture, and the mosque can accommodate about 15 thousand worshipers. Meanwhile, the "Brother Mentouri" University in the "Ain El Bey" region has been designed by the international architect "Oscar Niemeyer", which is a destination for those interested in attractive architectural artifacts, for the peculiarity of its design inspired by the basic tools of study such as the book, pen, ruler, inkwell, and sharpener, which gave it a unique external view in the world, and made it as a scientific edifice with a record full of genius names in various fields: scientific, intellectual and literary, learned or studied there. The International University of the "New town" of Constantine also worked to provide educational opportunities for many foreign students in various scientific disciplines that confirm the consolidation of the values of cultural exchange between societies in Constantine city (Belbacha, 2011).

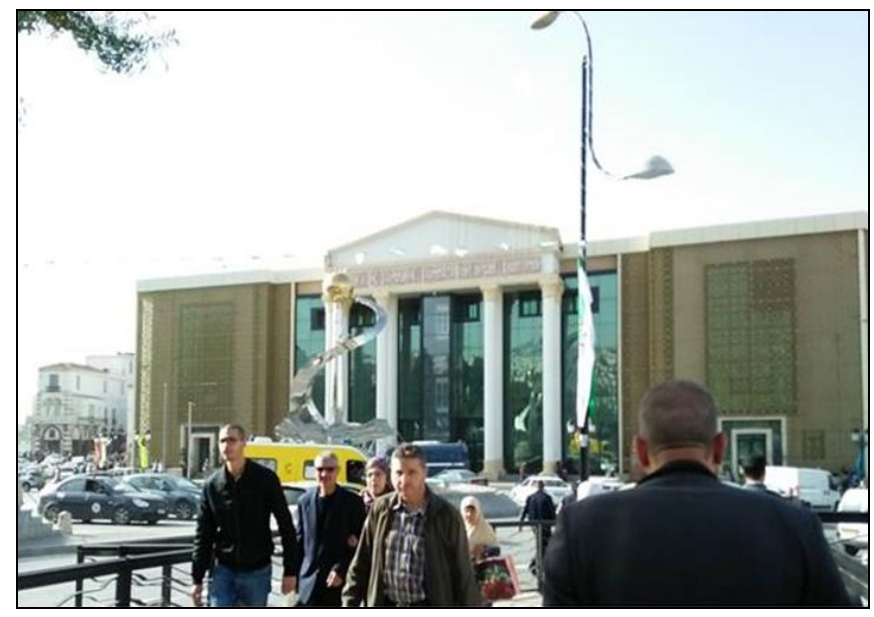

Figure 3. Cultural center "' Mohamed El-Aid Al Khalifa" in the city of Constantine (Source: Authors, 2019)

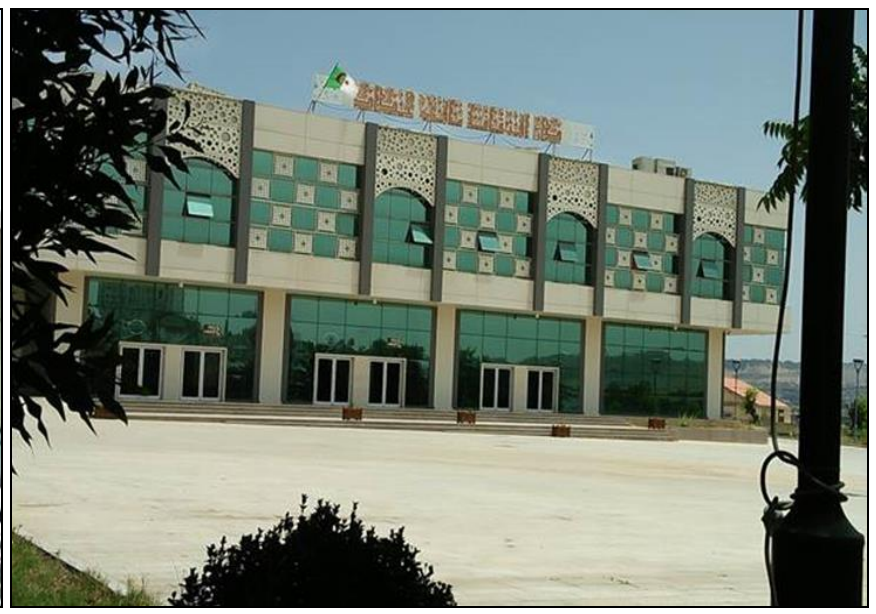

Figure 4. Cultural center "' Malek Haddad" in the city of Constantine (Source: Authors, 2021)

\section{High and avoidance roads and suspension bridges to extend the bonds of both solidarity and fraternity}

The roads linking different neighborhoods and cities express the desire for commercial, cultural and scientific exchange between different peoples in their customs and cultures, as well as bridges that challenge the difficulties posed by nature in the desire of societies in solidarity, fraternity and communication, which can be observed in many cities across different civilizations aimed at settling the features of peace and security among their peoples. While in situations of conflict and war, we note that the first thing to do by any enemy at the beginning of the confrontation is the bombing of roads, bridges, railways and the corridors of airports. Therefore, the first manifestations of conflict is the destruction of roads and bridges, and the manifestations of peace and security is to strengthen its presence, and this is what we find in the cities of As-Salt and Constantine, making the opportunities for peace tourism to be present intensively.

As-Salt is characterized by its difficult topography, which was reflected in the overcrowding of housing and its proximity to each other, the steep slopes of its roads, its narrowness, due to its geographical and demographic nature (Qtaishat et al., 2019), and Sixty Street was established to constitute roundabout that helps residents to move easily, and use alternative methods of internal roads in As-Salt city, which is difficult to take. Sixty street has become a tourist and recreational place for all city residents and suburbs (Figure 5). It extends from the first bridge " $\mathrm{Z}$ " to the end of the "Al Manshiya" area where the Al-Balqa Applied University is located, and its length ranges between seven to eight kilometers, and it opens the way for everyone to find a spatial space in which the residents enjoy a healthy atmosphere, and fresh air that helps exercise in every sport all the time and from both sexes during the summer and the holy month of Ramadan, the youth and families previously used to go to Amman, Aqaba, or the Dead Sea for walks, or to sit on Amman-Salt Road, except that the presence of Sixty Street has become a suitable alternative for families for hiking, exercising, and sitting for long hours may reach midnight in the summer, and until the dawn call to prayer in Ramadan (http://rasseen.com/art.php?id=36d4302b08bf0430ba1e9bbf48bd16ea99bc5570).

On the other hand, Constantine city is also characterized by its difficult topography and interruption among its terrain units, it has spread high and suspended bridges to link between the various neighborhoods of the city, facilitate movement, 
emphasized communication and continuity between different groups of society and their cultures as these bridges embody successive civilizations. Over the city, the bridge "Qantara" was constructed during the Roman period and was rebuilt in the late Ottoman period (1792 AD) (Bouchareb, 2006). Also, during the Ottoman period, the "Devil" Bridge was built at the bottom of the Sand Gorges. During the colonial period, several bridges were built. The most important of which was the "Sidi M'cid" bridge in 1909 AD, "Sidi Rashed” Bridge in 1912 (Figure 6), "Waterfalls" Bridge in 1928, "Mellah Suleiman” Bridge in 1917 AD, and "Saleh Bey" Bridge in 2014 AD (Figure 7) in the period of independence (Belbacha, 2011). Such bridges worked on connecting the city of traditional Arabic on the rock and the neighborhoods of "Prince Abdel Qader" and "Bab AlQantara" with the European style, while connecting the old city with the university hospital "Abdel Hamid ben Badis" and the "Mansoura" Plateau where the European style neighborhoods, such as "Sidi Mabrouk" neighborhood, "Mansoura" neighborhood, and "Al-Bosky" neighborhood as well as a link for new neighborhoods with a collective style, such as "Daksi" neighborhood, "Sakiet Sidi Youssef", "Ziyadia" and "Djamal Abdel Nasser" square and from there to "the beautiful scenery" neighborhoods, such as "Siloc”, "Fadila Saadane”, "Djenan El Zitoun”, "Boudjnana”, "Bousouf” (Benghadbane, 2001).

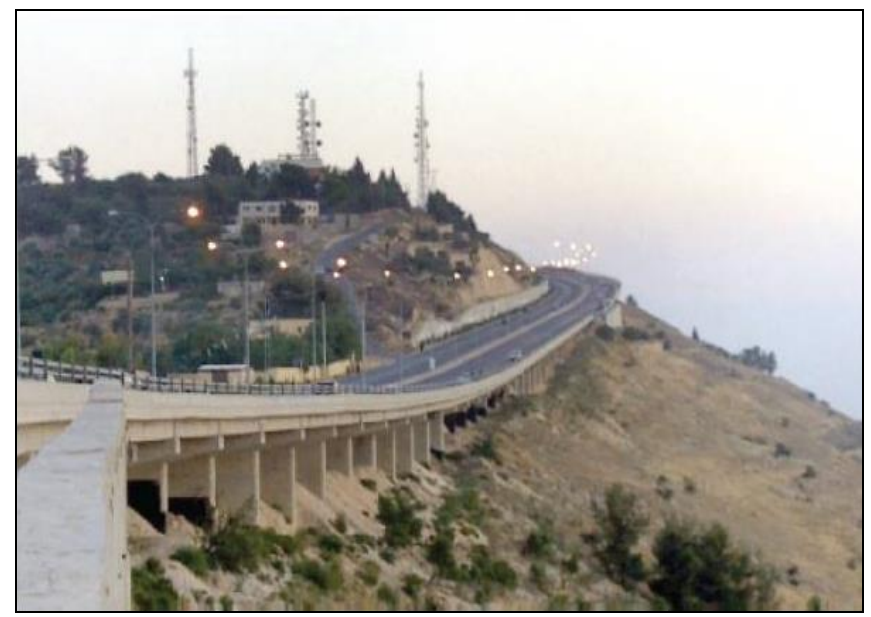

Figure 5. The road of "Sixty" in the city of As-Salt (Source: Archives of the municipality of Al-Salt)

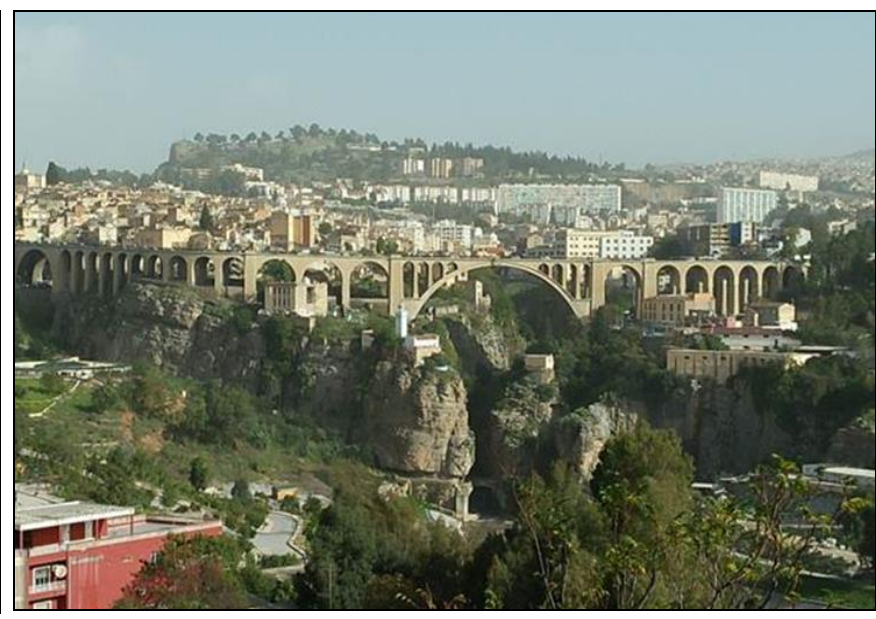

Figure 6. "Sidi Rashed" Bridge in the city of Constantine (Source: Authors, 2020)

\section{Multiple religious features that reflect the desire for tolerance and peace}

As a result of maintenance and preservation work, the spread and presence of religious monuments, such as Islamic, Christian, and Jewish in their good condition reflect the extent of the community's desire to tolerate interfaith and lay the foundations for peace and solidarity, as the city of As-Salt embraces many shrines of the prophets, and among them we can mention "Joshua bin Nun" , "Shuaib" (Figure 8), "Yeshua" (Figure 9), "Ayoub", "Jad Bin Yaqoub", "Djadoor", the shrines of the Companions, "Ubaidah Bin Al Jarrah", and "Dhir Bin Al Azwar", which are places where many people, researchers, historians, writers and tourists come to, and where victims and vows are presented, especially on holidays and religious occasions (http: // alrai.com/article/10444819). In addition, there are many churches, such as the Church of the Virgin Mary's Rest, the shrine and the Church of the Greens, and the Latin Church, adjacent to the mosques (the Great Mosque, the Small Mosque) and the Evangelical Complex (Alzoabi, 2004).

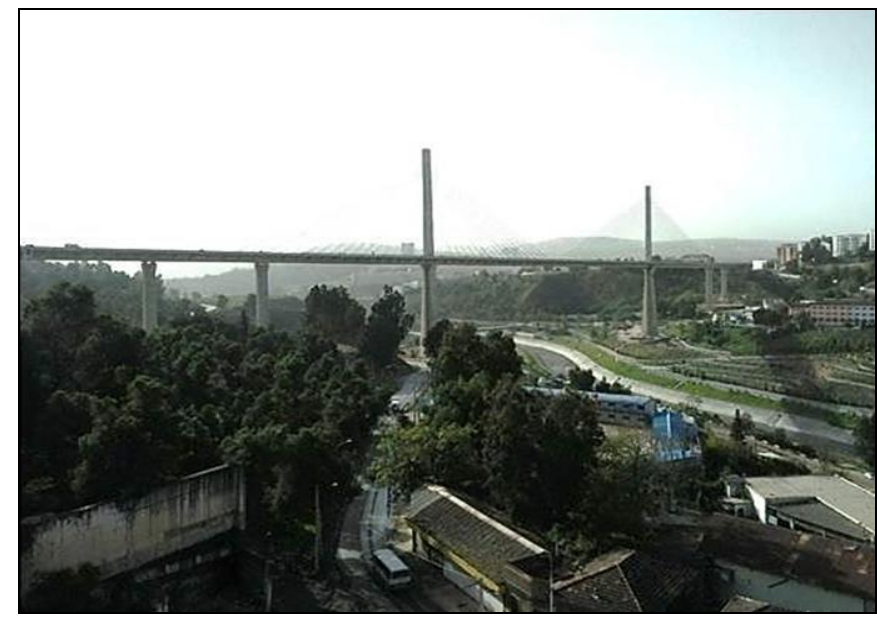

Figure 7. "Saleh Bey" Bridge in the city of Constantine (Source: Authors, 2020)

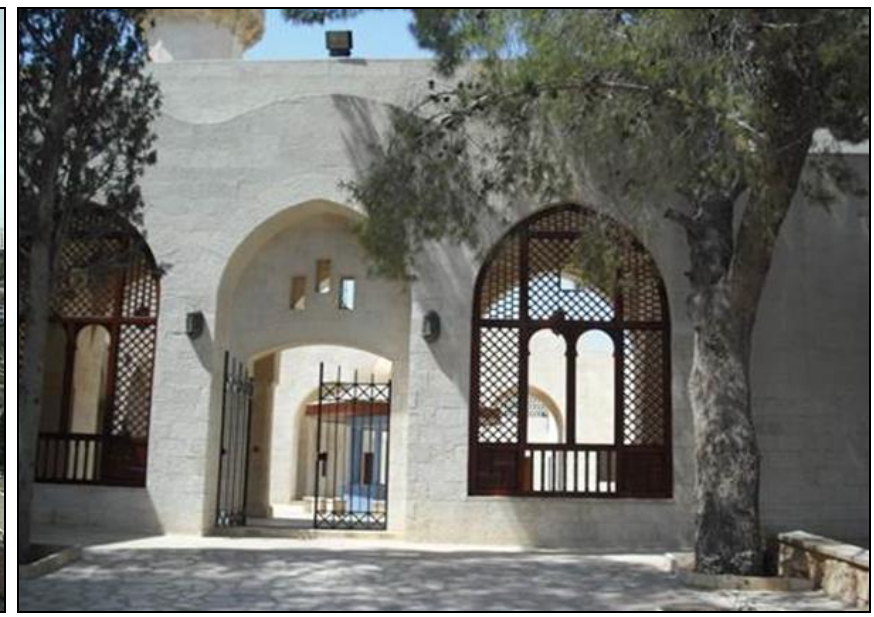

Figure 8. "Shuaib" shrine in the city of As-Salt (Source: Authors, 2018)

In the city of Constantine, religious tolerance and a desire for peace are evident through the presence of the statue of Our Lady of Peace "Virgin Mary" on the tops of Mount "Sidi M'Cid" overlooking the slopes of the "Mansoura" Plateau 
and its adjacent to the Jewish cemetery that has been preserved by the local community of the city next to the mosque of "faith" and on the left of All of that was established "the monument of the dead" and here we find the coexistence of the three divine religions: the Jewish religion, the Christian religion, and Islam which gives the city of Constantine the prestige and reverence of the sacred ancient cities in which civilizations and religious beliefs are known to man since the dawn of history. It is worth noting that central Islamic cemetery of the city is adjacent to and close to the Christian cemetery in the neighborhood of "Belouizdad". Also, Jewish residences still exist in the city of Constantine in the neighborhood of the street, and among them is the residence (house) of the international singer "Enrico Macias" alongside the synagogue of Jews near the "El Asr" market below "d'Aumale" high school. Moreover, many ancient and modern mosques are scattered all over the city along with the corners, namely: "Rahmaniyya", "Tijaniya", "Tayyibi", and "Hanasul" as well as the shrines in the old city, Sidi Mabrouk, and Sidi M'Cid neighborhoods (Ahraw, 2013).

\section{Museums are a memory of people's civilizations and cultures:}

The "Salt Historic Museum" is the most important museum in the city and in the Kingdom as well, which carries among its walls the history of the city in all its aspects, it is one of the houses with great architecture overlooking "Al Ain" Square, and it is so-called as "Abu Jaber House" (Figure 10). It has been established in 1893 by the constructor Al-Nabulsi "Al-Haj Abdul Rahman Al-Aqrouq" and finished in 1906. It is known that he used the basement as a warehouse for supplies, firewood, hay, and as an animal store, while the first floor was an addition and a place for holding banquets. Upon the announcement of Great Arab Revolution, the representative of Prince Abdullah stayed there for three months before declaring As-Salt as the capital of the Emirate of Transjordan (Zalloum and Tarrad, 2020).

In the city of Constantine, the Museum "Cirta" stands out as the oldest museum in Algeria (Figure 11), where its establishment was an imperative to house and collect the huge number of artifacts discovered in the city while converting its northern part to a European city during French colonialism, due to the efforts of archaeological association of the province of Constantine, which has an active role in the establishment of the museum that was inaugurated in 1931(Belbacha, 2011), as the museum was known in the framework of the Constantine demonstration as the Capital of Arab Culture (2015). Preparation works affected a number of its halls in which he received a large number of foreign visitors from various fraternal Arab states as well as from European friendly countries to see the various artifacts. Most of which date back to the Numidian period, as Constantine was the capital of the Numidian queen under the name of "cirta", and it is worth mentioning that during the year 2015, the Cirta Museum accommodated more than 5,000 visitors such as Algerians and foreigners (Directorate of Tourism and Traditional Industries of Constantine, 2016).

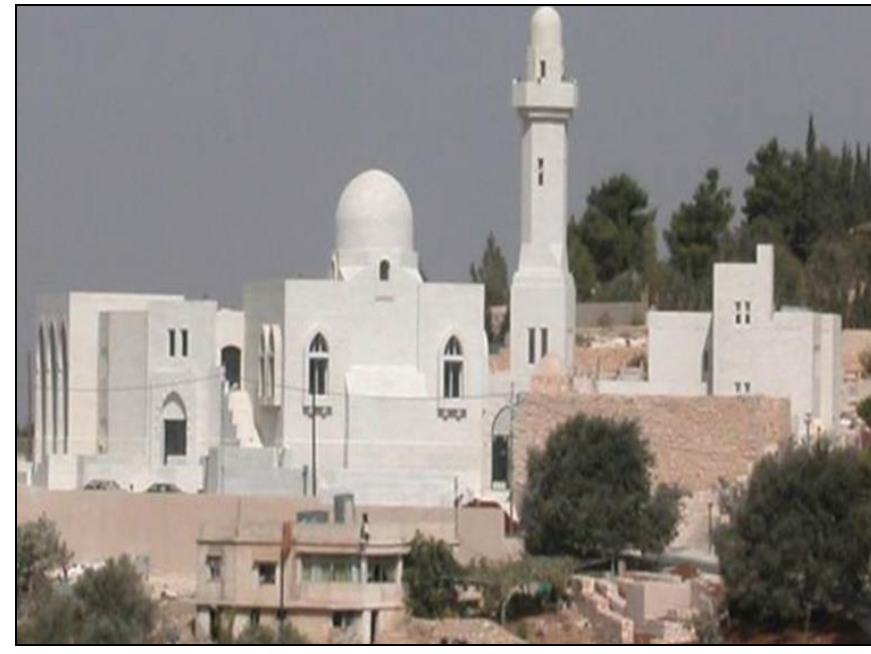

Figure 9. "Yeshua" shrine in the city of As-Salt (Source: Authors, 2018)

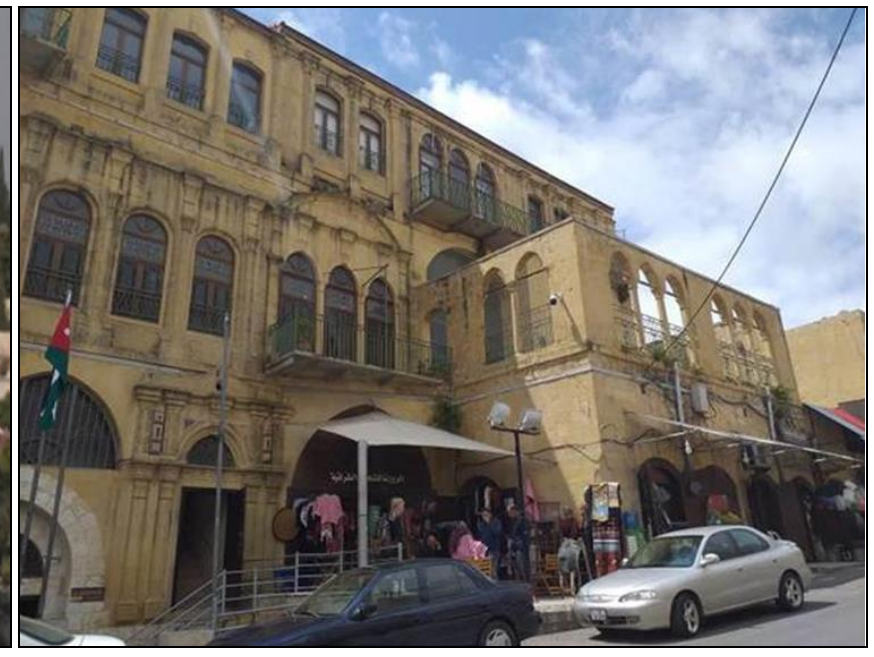

Figure 10. "Abu Jaber" Museum in the city of As-Salt (Source: Zalloum and Tarrad, 2020: 364)

\section{Cafes and Guesthouses Reflecting Customs and Traditions:}

There are many heritage restaurants in As-Salt city, such as "Al-Gherbal", "Al-Amad", and "Tawahin Salt" seek to provide meals that reflect the customs and traditions of the Sultan community as well as guest houses which are represented in "Aziz House" that was built in the beginning of the nineteenth century as a social project for tourists that is distinguished by its ancient heritage character, and its stunning view of Al-Jada'a Mountain on the heritage castle mountain, "Al Ain" Square, "Al-Hamam" Street, and the most important churches and mosques in the ancient city of As-Salt. Also, the house consisted of 12 hotel rooms, including 5 hotel rooms equipped with the latest amenities, where the rooms are rented at promotional prices. Aziz House is the first heritage hotel in the center of As-Salt city that receives visitors to As-Salt city in the reception halls containing pictures, manuscripts and a library dealing with history the architect and socialist of the city.

"Abu Al Samman" emphasized that the visitor has an opportunity to experience the traditional cuisine prepared by the region's ladies in the house of Aziz's kitchen, in addition to the experience of preparing local sweets that are popular in As-Salt city, and traditional fizzy drinks of tea and Arabic coffee and aromatic herbs that grow in Region (http://alrai.com/article/535133.html). As-Salt is also famous for its heritage cafes, including the "Zamanak Ya As-Salt" 
café, which is the first of its kind in As-Salt. It is represented in an ancient antique house that exceeds 120 years old, and is distinguished by its architectural style that was famous in that era that is illuminated by its yellow stones, its distinctive, and unique contrasts where the grounds of the cafe are littered with red heritage rugs, the entrance to the cafe is decorated with vineyards, the large berry tree that is almost empty of all the royal houses.

Also, it features its golden stones, which are laden with stories and tales of this ancient city, the details of the story of religious coexistence where four families lived in this same house, two Christian families and two Muslim families who lived in the same place, with one yard, a shared kitchen, and its members ate from the same plate.

Constantine city is characterized by its popular restaurants and cafes that offer services to those who go frequently whether to the local residents or to the tourists who come from different sides of Algeria or even foreigners, and from these places stands out clearly the "Nedjema" cafe (Figure 12) that has remained entrenched from the collective memory of the city's residents despite its simple nature. It is considered as the identity of the city, which is strengthened by its famous buildings and historical landmarks. It was established in 1928 by its owner, "Al-Hajj Khojah Al-Ajabi", next to "Abdel Hamid Ben Badis Old School", "Al-Shatt" and the "Forty Sharif" neighborhoods where the Association of Muslim Scholars was located. Sheikh "Abdel Hamid ben Badis" was sitting in this cafe, and other personalities who studied at the school, including the late President "Houari Boumediene", "Mohamed Boudiaf", "Rabah Bittat" and "Ismail Hamdani". The café also meant the elders of the composer and the musician Zawawi, Muhammad Al-Tahir AlFurqani, who were sitting in the "Nedjema" cafe before and after performing the music, and many of the workers of the tobacco factory "Benchikou" nearby who were passionate about the traditional Constantinople were gathering in the "Nedjema" cafe to talk about the art of "the familiar" and "Al-Esawah", as the "Nedjema" cafe was in the past a station that must be stopped for those who pass through the city on their way to the train station, "Nedjema" cafe is characterized by wooden décor and colored porcelain similar to its status previously without making any change. Some musical instruments were hung on its walls, photographs, some of which are old, reminiscent of days. Consequently, "Nedjema" Cafe remains the memory of an entire city and has a history of nearly 100 years (Ahraw, 2013).

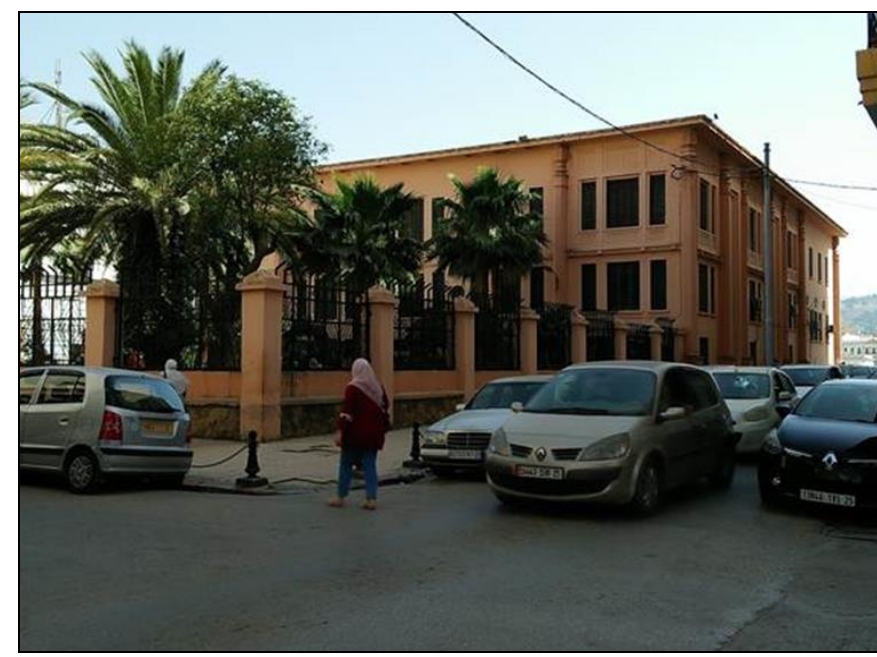

Figure 11. "Cirta" Museum in the city of Constantine (Source: Authors, 2021)

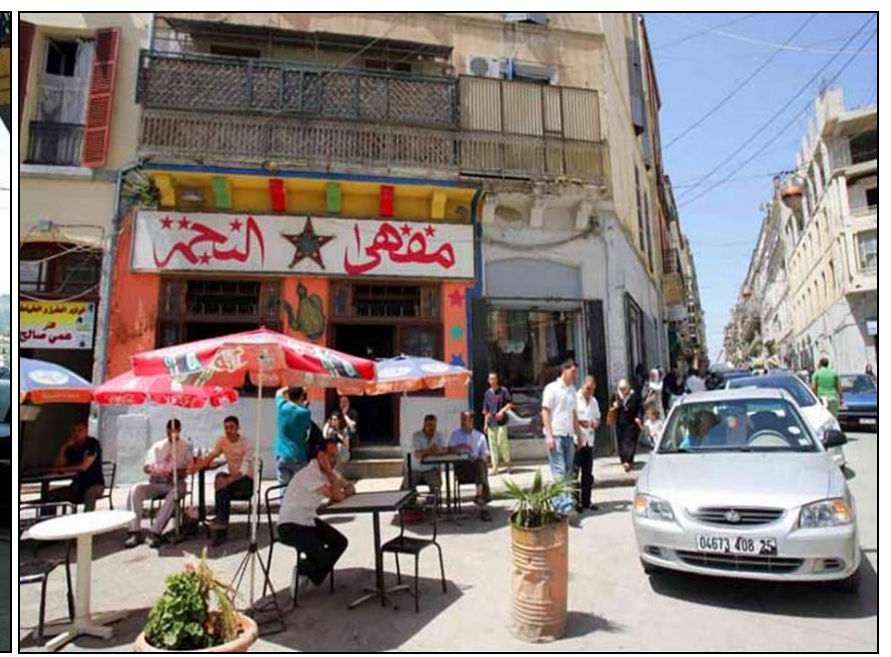

Figure 12. "Nedjema" cafe in the city of Constantine (Source: Archives of the Directorate of Culture of the wilaya of Constantine)

\section{Traditional Crafts and Industries for Cultural Exchange:}

As-Salt city is distinguished, like other Arab cities, with the commercial specialization of its streets, which is characterized by the gathering of the owners of one craft in a specific place, and there are many works and traditional crafts in the authority and many skilled craftsmen scattered in many shops in "Hammam" Street, the Green Street, the lower municipal street where blacksmiths, shoemakers as well as barbers gather, and stores selling Arab sweets and spices (Zalloum and Tarrad, 2020). In regard to Constantine city, it is well-known for its traditional crafts rooted in its history and connected to its origin, which is the gold industry through many ornamental jewelry are produced for women where there are specialized alleys for the jewelers' shops in the old city, as well as the copper industry from which traditional utensils and tools are made for decoration. Also, the copper industry from which traditional utensils and tools are madefor decoration and home use (Ahraw, 2013). Many stores were found in Constantine city, but most of them are concentrated in "Bardo" district, which is devoted to this type of traditional industries dedicated to it is known as tailors Street as well as dessert stores (Boudjadja, 2014). All these traditional crafts enriched the cultural life of the two cities and became an integral part of the cultural tourism of the two cities.

\section{Heritage tourism reinforced by the sovereignty of peace and security:}

Heritage sites are considered as essential resources to legalize a specific social reality, which often emphasizes the differences between societies (Graham et al., 2000; Lowenthal, 2005). Therefore, As-Salt city is dominated by heritage tourism based on the many heritage buildings densely populated there, which was built by reservation with a yellow stone that take semi-unified architectural forms, especially in the form of windows, doors, and balconies where heritage 
tourism depends mainly on the local community of the city, i.e. its residents as in 2005. Therefore, they work to introduce and provide various explanations for their tangible and intangible cultural resources (Al Bqour, 2020). As such, touristic tours are distinguished in the city, which take approximately three hours, with the presence of a tour guide who guides tourists about the characteristics of the city, organizes visits to heritage homes and the guest house, identifies the most prominent customs of the city by using an actual application that includes providing Arabic coffee, and eating a home lunch Traditional such as "Maqlobah" and "Khabeesa", dresses in some traditional clothes, and attends a ceremony for resolving disputes and reforming individuals (http://saltcitytour.com).

Due to the importance of tourism in As-Salt city many projects were found to rehabilitate and preserve its landmarks, which were concerned in the market area, Al-Hamam Street, stairs, and narrow roads, squares, and places where people gather for entertainment, leisure and public gatherings (Daher, 2005). It is a study of the Scientific Society Ownership (RSS) of As-Salt, prepared by the Royal Scientific Society in cooperation with the Planning and Organization Department in the Municipality of As-Salt, and commissioned by As-Salt Development Company (SDC), and with funding from the United States Agency for International Development during the period (1989-1990) which included the development of the architectural record of the traditional buildings of the city. Then, the process of basic survey of cultural resources in As-Salt by Japanese project of the International Agency "JICA", which is regarded as another contribution in the process of surveying cultural resources in As-Salt city which was called "Basic Survey of the cultural resources in As-Salt". As a result, 1019 heritage sources were identified and illustrated in a photo folder with all the information related to the buildings, to the nature of the employed materials, the building number, and the general condition. Euronet Consulting firm "financed by the World Bank for Tourism Development WB3, models were developed to accommodate 100 traditional buildings according to their cultural importance in the central region of As-Salt with documentation of 20 selected buildings, protection areas, and development corridors that are subjected to special provisions that were proposed as a part of the proposed master plan in order to include shelter pens, heritage corridors, the process of rehabilitation of buildings and squares in the historical city of As-Salt that contained funding to strengthen the facades of "Al-Hammam" Street by the United States Agency for International Development (USAID), which is an early attempt in the early nineties, followed by the conversion of the Toukan house to the archaeological museum of the Sultanate by Tahan and Bushnaq and their implementation by Amer Al-Khatib (Fakhouri and Haddad, 2017).

Another traditional project on "Hammam" Street was also included in another renovation project along with the support of the Securities Depository Center, where an attachment for a prayer hall was added to the upper floor, and a new facade was built in front of the original façade behind the modern addition. Also, "JICA" as part of the tourism sector development project implemented a project to reuse "Abu Jaber House" in the historic old As-Salt Museum as well as the establishment of panoramic outlets and the renovation of "Al Ain" Square (the closest section to the mosque), and the process also included the improvement of four panoramic views $\left(1200 \mathrm{~m}^{2}\right)$, paths and ladders $(7 \mathrm{~km})$, and for open spaces including $\mathrm{Al}$ Ain Plaza to enhance the built environment (Fakhouri and Haddad, 2017) which had a reflection on the recovery of the number of tourist arrivals that included less than 638 tourists in 2013 and then increased to 968 tourists in 2015 and the continuation of the rise is expected after the completion of the rest of the conservation and maintenance projects for heritage buildings. It should be noted that the number of tourists was about 2,675 tourists in 2007 (Jamhawi and Hajahjah, 2017).

In respect of Constantine city, it acquires many and various tourism components. Therefore, it is not possible to define a specific pattern for the prevailing tourism in it, as heritage, religious, mountain, and business tourism. It can be practiced through security, stability and peace that prevail in the city. In this context, the city has benefited from several major urban projects, represented in the completion of "Saleh Bey Bridge", the air elevator project, the tramway project, and a group of hotels such as Marriott and IBIS (Rebai, 2010) and many interventions on the building facade on the main roads of old city (Boufenara, 2008) such as "Larbi Ben M'hidi" Street and "June 19" Street (Hecham-Zehioua, 2010). In addition, provide adequate housing, eliminate chaotic housing (Nait-Amar, 2015), and prepare the squares of the city center such as "La bréche" Square and "El Kerkeri" Square (Rebai, 2010).

All of which improved the urban image, and provided many services, such as transportation, health, and feeding and expanded the capacity of hotel accommodation to be a tourist destination that attracts tourists, facilitates, and increases opportunities for communication and friction between different cultures, which had a reflection on providing job opportunities in the hotel sector as the workforce increased from 327 employees in 2009 to 966 employees in 2015. The number of tourists' arrivals to the city increased. For instance, the number of Algerian tourists increased from 96,446 in 2012 to 141,137 in 2015, while the number of foreign tourists increased from 13.202 in 2012 to 28,472 in 2015 (Directorate of Tourism and Traditional Industries of Constantine, 2016).

\section{Findings of the Study}

In light of the above, the following results were reached:

- As-Salt and Constantine's cities present a culture of peace among members of their societies as they are considered as host communities for tourists who come to them from different geographical destinations.

- As-Salt and Constantine cities are an area of cultural exchange which is evident through customs and traditions that can be touched and perceived by ancient restaurants and cafes, and through crafts and traditional industries (Traditional clothing, copper industry and gold industry).

- As-Salt and Constantine cities are considered as a model of brotherhood and tolerance between the monotheistic religions in society within the framework of respecting the principles and political orientations of both countries in which each city resides. 
- As-Salt and Constantine cities acquire many urban features that will achieve peace tourism within them and here it is clear that the prevailing peace in both cities contributes to the creation of tourism.

- The heavily existing urban features allow As-Salt and Constantine cities to find different types of tourism. As such, tourism is able to provide peace through the opportunities it enjoys.

- Heritage tourism is considered as one of the most important type of tourism practiced in both As-Salt and Constantine cities, but more severe and deeper in As-Salt city.

- There is an active participation of the local community in developing heritage tourism in As-Salt city, while it is less in Constantine city.

- Constantine city witnessed a remarkable development in the number of tourists' arrivals after the return of security and peace, and its support for many service facilities that would enrich and improve its tourist destinations.

\section{Recommendations}

Based on the foregoing, and for the purpose of establishing peace tourism in both As-Salt and Constantine cities and achieving their sustainability, the following recommendations can be concluded:

-Developing heritage tourism in both As-Salt and Constantine cities because such type of tourism promotes the dialogue between cultures

- Encouraging social contact among individuals due to its role in acknowledging cultures.

- Increasing the awareness of tourism due to its magnificent role in increasing peace and understanding among different societies.

- Encouraging community participation in tourism development due to its role in defining the way of change towards sustainability, particularly in Constantine city.

- Heritage tourism constitutes the most suitable and appropriate alternative in both As-Salt and Constantine city in achieving sustainability, as it is considered as a spatial area for strengthening relations and peace on the one hand and reflecting the civilizations of previous generations to future generations.

- Guaranteeing plans for improving heritage tourism by taking into consideration sustainable development, such as economic, social, and environmental by considering it represents a model of the relation that connect between social tourism development, heritage, and peace-building.

- Keening on the completion of conservation and preservation process of heritage building for As-Salt city, particularly because it is classified from UNESCO organization as a global heritage, urging the local community to the necessity of maintenance and repair the heritage buildings in Constantine city, particularly in the lower section of the city "Souika" for enhancing heritage tourism because it is close to "Sidi Rached" bridge.

- Setting up urban projects to advance heritage tourism in the city of Constantine by accelerating the preparation of the "La Bréche" square in the city center of Constantine city and the "Bardo" tourist park project.

-Providing specialized museums in both cities since various heritage buildings in As-Salt city for establishing museums and embarking on completing "Arts" Museum in "Al-Qantara" district next to the "High Urban Library" in Constantine city.

- Increasing the number of shops for selling antiques and souvenirs in As-Salt city, especially by the track of "Sixty Street" where most tourists pass through, and accelerating the completion of the artisan village for making copper-ware and engraving on copper in the "Bardo" district since they consider as an ancient and artistic craft in Constantine city, and preparing the current stores with the underground corridors in the city center that are next to the Culture Palace of "Mohammed El-Aid El Khalifa" to sell artifacts and souvenirs.

- Encouraging guest houses in As-Salt city as an orientation to introduce the customs, traditions, and culture of the country. Also, seeking to stimulate cultural, sports, and cinematic, musical, and common artistic events in Constantine city.

- Strengthening the International University in the new town with new scientific specializations as it represents the continuity of Constantine's position as a city of science and scholars.

- Providing investment opportunities for the private sector in advancing tourism destinations within the framework of the understanding to achieve tourism and peace.

\section{CONCLUSION}

As-Salt (Jordan) and Constantine (Algeria) cities provide multi-faceted tourist destinations that allow the practice of many types of heritage, religious, mountain, business tourism and the existence of opportunities for peace tourism that are enhanced through the privacy of their urban features in establishing a culture of peace, understanding, dialogue, and intercultural exchange in both societies .Regardless the simple differences between them heritage tourism represents an appropriate alternative to change towards sustainability in light of the desire of the local community to participate in many tourism projects, the preservation and maintenance of heritage buildings, and their protection and decision makers orientation to adopt the principles of sustainable development that reflect the core of understanding, dialogue, and peace.

The study concluded the necessity to depict a model for the relationship between tourism, peace, and heritage development in both As-Salt and Constantine cities based on tourism planning that takes into account the privacy of the urban features in both cities within a rational tourism management that works in involving all actors, residents, decision makers, government investors, and properties to embody peace tourism and its continuity across generations.

\section{REFERENCES}

Ababsa, M. (2011). Citizenship and Urban Issues in Jordan. Cities: Urban Practices and Nation Building in Jordan. Presses de l'Institut français du Proche-Orient, Beyrouth, 39-64. 
Ahraw, W. (2013). Urban Heritage: A Tool for Activating Sustainable Tourism, Case of Greater Constantine. Thesis of Magister, University of Oum El Bouaghi, Algeria.

Al Bqour, N. (2020). The Impact of World Heritage Site Designation on Local Communities / As - Salt City as a predicted case study. Journal of Civil \& Environmental Engineering, 10 (4), 1-6. https://doi.org/10.37421/jcce.2020.10.348

Almatarneh, R.T. (2013). Sustainability lessons learnt from traditional architecture: a case study of the old city of As-Salt, Jordan. Journal of Environmental Science, Toxicology and Food Technology. 5(3), 100-109. https://doi.org/10.9790/2402-053100109

Alzoabi, A. (2004). The Influence of Building Attributes on Residents' 'Images of the Past' in the Architecture of Salt City, Jordan. International Journal of Heritage Studies, 10(3), 253-275. https://doi.org/10.1080/1352725042000234442

Ariana, N., Sukana, M., \& Ariana, N.J. (2016). Preference of tourists toward peace tourism product for Ground Zero Monument in Kuta Bali. Journal of Indonesian Tourism and Development Studies, 4(2), 63- 66. https://doi.org/10.21776/ub.jitode.2016.004.02.03

Attal, R. (1996). Perspectives on the Jews of Algeria. Harmattan, Paris. (In French).

Belbacha, M.L. (2011). The tourist load capacity within the urban project approach for sustainable tourism: Case of Constantine. Thesis of Magister, University of Constantine, Algeria.

Benghadbane, F. (2020). The influence of mother-city urban planning on satellite cities: A case study of Constantine, Algeria. Test Enginnering \& Management, 83, 2712-2725. https://www.testmagzine.biz/index.php/testmagzine/article/view/4068

Benghadbane, F., \& Khreis, S. (2019). The role of tourism marketing in enhancing tourism development: a comparative study between Constantine and Amman cities. GeoJournal of Tourism and Geosites, 24(1), 146-160. https://doi.org/10.30892/gtg.24112-349

Benghadbane, F. (2001). Satellite cities around Constantine: its transformations, roles and functions. Thesis of Magister, University of Constantine, Algeria.

Bouchareb, A. (2006). Cirta or the urban substratum of Constantine : the region, the city and architecture in antiquity (a study in urban archeology). Thesis of doctorate, University of Constantine, Algeria.

Boudjadja, R. (2014). The environmental dimension in the urban regeneration project of the Bardo district in Constantine. Thesis of Magister, Polytechnic School of Architecture and Urbanism, Algiers.

Boufenara, K. (2008). Rehabilitation as a process of the urban project: case of Constantine. Thesis of Magister, University of Constantine, Algeria.

Boukerzaza, M. (2015). The revaluation of built heritage by the requalification of public spaces, Case of the Medina of Constantine (Algeria) and the eco-district Vauban in Freiburg im Breisgau (Germany). Thesis of doctorate, Jean Monnet University, Saint Etienne, France.

Boyd, S.W. (2000). Heritage Tourism in Northern Ireland: Opportunity under Peace. Current Issues in Tourism, 3(2), $150-174$. https://doi.org/10.1080/13683500008667871

Causevic, S., \& Lynch, P. (2011). Phoenix tourism: Post-conflict tourism role. Annals of Tourism Research, 38(3), 780-800. https://doi.org/10.1016/j.annals.2010.12.004

Daher, R.F. (2005). Urban regeneration/Heritage tourism en devours: The Case of Salt, Jordan 'Local Actors, International Donors, and the State'. International Journal of Heritage Studies, 11(4), 289-308. https://doi.org/10.1080/13527250500235575

Da Silva, J.T., Breda, Z., Carbone, F., \& Govcopp. (2021). Role and Impact of Tourism in Peacebuilding and Conflict Transformation. D'Amore, L. (dir). IGI Global.

D'Amore, L. (1988). Tourism - The World's Peace Industry. Journal of Travel Research, 27(1), 35-40. https://doi.org/10.1177/ 004728758802700107

Does, L., \& Kawano, N. (2017). Can the Atomic-bomb Experiences be conveyed through "Peace tourism"? : The Case for a "Participatory Heritage" Approach. Hiroshima Peace Science, 39, 95-115. https://doi.org/10.15027/45731

Fakhouri, L., \& Haddad, N. (2017). Aspects of the architectural and urban heritage: from registers to conservation for adaptive and modern use at the historic cores of Salt and Irbid, Jordan. International Journal of Architectural Research, 11(2), 190-218. https://doi.org/10.26687/archnet-ijar.v11i2.1256

Farmaki, A. (2017). The tourism and peace nexus. Tourism Management, 59, 528- 540. https://doi.org/10.1016/j.tourman.2016.09.012

Fakhoury, L., \& Haddad, N. (2014). Manual for the conservation of the Historic Centre of Salt, (in Arabic), CultTech, Amman. https://issuu.com/asociacionrehabimed/docs/manual_as_salt

Graham, B., Ashworth, G.J., \& Tunbridge, J.E. (2000). A geography of heritage: Power, culture, and economy. New York: Oxford University Press.

Herath, N. (2010). Peace Through Tourism: Beyond Intractability. Eds. Guy Burgess and Heidi Burgess. Conflict Information Consortium, University of Colorado, Boulder. http://www.beyondintractability.org/essay/peace-through-tourism

Hecham-Zehioua, B. (2010). Impacts of projects registered in Constantine and evaluation of its brand image, for an urban project with structuring effect. Thesis of doctorate, University of Constantine, Algeria.

Hyasat, A.S., \& Alnahleh, M.A. (2014). Understanding the Current Conditions of Tourism Product and Tourism Perceptions in As-Salt City, Jordan. Journal of Management and Sustainability, 4(4), 147- 160. https://doi.org/10.5539/jms.v4n4p147

Jamhawi, M.M., \& Hajahjah, Z.A. (2017). A bottom-up approach for cultural tourism management in the old city of As-Salt, Jordan. Journal of Cultural Heritage Management and Sustainable Development, 7(1), 91-106. https://doi.org/10.1108/JCHMSD-07-2015-0027

Jimenez, C., \& Kloeze, J.T. (2014). Analyzing the Peace through Tourism Concept: The Challenge for Educators. Sociology and Anthropology, 2(3), 63-70. https://doi.org/10.13189/sa.2014.020301

Khirfan, L. (2013). Ornamented Facades and Panoramic Views: The Impact of Tourism Development on al-Salt's Historic Urban Landscape. International Journal of Islamic Architecture, 2(2), 307- 324. https://doi.org/10.1386/ijia.2.2.307_1

Kunwar, R.R. (2006). Tourists and tourism: Science and industry interface. International School of Tourism and Hotel management, Kathmandu.

Larouk, M.H. (1984). Constantine City: A Study in Urban Geography. OPU, Algiers.

Lee, Ch.K., Bendle, L.J., Yoon, Y.S., \& Kim, M.J. (2012). Thana tourism or peace tourism: Perceived value at a North Korean resort from an indigenous perspective. International Journal of Tourism Research, 14, 71-90. https://doi.org/10.1002/jtr.836

Lipietz, A., (2007). Algeria: From civil harmony to the Charter for Peace and National Reconciliation: Amnesty, amnesia, impunity. (in French). http://lipietz.net

Lowenthal, D. (2005). Natural and cultural heritage. International Journal of Heritage Studies, 11(1), 81-92. https://doi.org/10.1080/13527250500037088 
Mishra, P., \& Verma, J. (2017). Tourism and peace in economic development perspective of India. Journal of Environmental Management and Tourism, 4(20), 927-934. https://doi.org/10.14505/jemt.v8.4(20).23

Moufakkir, O., \& Kelly, I. (2010). Introduction- peace and tourism: Friends not foes. In Tourism, progress and peace. Stenden University, Leeuwarden, Netherlands, pp. xvi-xxxii. https://doi.org/10.1079/9781845936778.0000

Mohanty, P., Rout, H., \& Samal, A. (2019). Community based Sustainable Tourism Development, a tool for fostering and promoting peace: A case study of Odisha, India. African Journal of Hospitality, Tourism and Leisure, 8(1), 1- 15. http//: www.ajhtl.com

Nait-Amar, N. (2015). Housing and living in the shanty towns of Constantine: Conditions and evolutions. Thesis of doctorate, University of Constantine, Algeria.

Pagand, B. (1994). From the Arab city to the European city: Architecture and urban formation in Constantine in the 19th century. Revue du Monde Musulman et de la Méditerranée, 73-74, 281-294. (in French). https://doi.org/10.3406/remmm.1994.1682

Pedersen, S.B. (2020). A Passport to Peace? Modern Tourism and Internationalist Idealis. European Review, 28(3), $389-402$. https://doi.org/10.1017/S1062798719000516

Pratt, S., \& Liu, A. (2016). Does tourism really lead to peace? A global view. International Journal of Tourism Research, 18(1), 82-90. https://doi.org/10.1002/jtr.2035

Qtaishat, D.A., Abd Al Azez Hdoush, A.A., \& Alzu'Bi, L.Q. (2019). Development of the Road Network in the City of Salt in 2004 and 2016 Using GIS. Modern Applied Science, 13(10), 94- 111. https://doi.org/10.5539/mas.v13n10p94

Qtiashat, D., Makhmreh, Z., Abu Taleb, H., \& Khlaifat, A. (2018). Urban Land Use Pattern and Road Network Characteristics Using GIS in Al Salt City, Jordan. Modern Applied Science, 12(4), 128-142. https://doi.org/10.5539/mas.v12n4p128

Rebai, H. (2010). Impact of urban renewal by structuring modernization projects, case of Constantine. Thesis of Magister, University of Constantine, Algeria.

Rowen, I. (2014). Tourism as a territorial strategy: The case of China and Taiwan. Annals of Tourism Research, 46, 62-74. https://doi.org/10.1016/j.annals.2014.02.006

Salazar, N. (2006). Building a "Culture of Peace" through Tourism: Reflexive and analytical notes and queries. Universitas Humanística, 62, 319- 333.

Shin, Y.S. (2005). Safety, security and peace tourism: The case of the DMZ area. Asia Pacific Journal of Tourism Research, 10(4), 411426. https://doi.org/10.1080/10941660500363777

Upadhayaya, P.K. (2016).What Tourism Security Means for Nepal? Journal of Tourism \& Hospitality, 5(2), 1- 12. https://doi.org/10.4172/2167-0269.1000211

Trillo, C., Aburamadan, R., Udeaja, C., Moustaka A., Baffour K.G., \& Makore B.C.N. (2020). Enhancing Heritage and Traditional Architecture Conservation Through Digital Technologies. Developing a Digital Conservation Handbook for As-Salt, Jordan. In Smart Innovation, Systems and Technologies, 177, 211-219. Springer, Cham. https://doi.org/10.1007/978-3-030-52869-0_18

Wohlmuther, C., \& Wintersteiner, W. (2014). Tourism and peace - an emerging field of action and research. In The International Handbook on Tourism and Peace, 17-28, DRAVA VERLAG, Austria.

Zalloum, B., \& Tarrad, M. (2020). The role of public spaces in reviving the historical areas: The case study of As-Salt city in Jordan. International Journal of Sustainable Development and Planning, 15(3), 361- 367. https://doi.org/10.18280/ijsdp.150313

Zulafqar, A. (2018). Impact of Turmoil and Peace on Tourism Industry in Jammu and Kashmir. International Journal of Research in Social Sciences, 8(2), 42-47. http://www.ijmra.us

*** Directorate of tourism and crafts of the wilaya of Constantine, (2016). Annual Report. Constantine, Algeria.

*** Greater As-Salt Municipality (2016). Geographical information Systems Department, unpublished data.

*** Institute for Economics and Peace. (2015). Global peace index: Measuring peace, its causes and its economic value. IEP Report (34), Australia.

*** ONS: National Office of Statistics, (2011). The urban frame RGPH 2008: The main results of the exhaustive exploitation. National Office of Statistics, Algiers.

*** World Travel \& Tourism Council, (2016). tourism as a driver of peace: Quantitative analysis on the link between peace and tourism. World Travel \& Tourism Council, London, United Kingdom.

http://www.scielo.org.co/scielo.php?script=sci_arttext\&pid=S0120-48072006000200012\&lng=en\&nrm=iso

http://www.beyondintractability.org/essay/peace-through-tourism

https://ofm.org/blog/king-abdullah-ii-of-jordan-receives-the-lamp-of-peace-award-in-assisi/

http://lipietz.net 